\title{
COMPARISON OF THE PRODUCTION AND CHEMICAL CONSTITUENTS OF FIVE PERILLA FRUTESCENS (L.) BRITT. ACCESSIONS
}

\author{
Péter RadÁcsi, * SzILVIa SÁrosi, Lotti ÁGnes Szomor and \\ Éva NÉMETH-ZÁMBORI \\ Department of Medicinal and Aromatic Plants, Szent István University, Budapest, Hungary
}

(Received: June 19, 2017; accepted: September 13, 2017)

\begin{abstract}
An open field experiment was carried out with five purple Perilla frutescens accessions (588P, GB, J3, JTD3, PS3) in 2014 and 2015. Morphological traits, production, total phenolic content (TPC), essential oil content (EOC) and composition as well as the antioxidant capacity (AOC) were investigated. Highest biomass was produced by JTD3 in both years. The antioxidant capacity and total phenolic content in the stems was lower than in the leaves in all accessions. Leaves of accession GB produced the highest AOC values (215.594 \pm 1.437 in 2014 and $86.609 \pm 3.602 \mathrm{mg} \mathrm{AAE} \mathrm{g}^{-1}$ in 2015 , respectively) while the strain 588P showed the lowest values (139.544 \pm 1.934 in 2014 and $38.966 \pm 4.569 \mathrm{mg} \mathrm{AAE} \mathrm{g}^{-1}$ in 2015 , respectively). The highest TPC values were measured by PS3 in 2014 (204.320 $\left.\pm 1.822 \mathrm{mg} \mathrm{GAE} \mathrm{g}^{-1}\right)$ and GB in $2015\left(136.450 \pm \mathrm{mg} \mathrm{GAE} \mathrm{g}^{-1}\right)$. The 588P produced the highest essential oil content $\left(1.432 \mathrm{ml} 100 \mathrm{~g}^{-1}\right.$ $\mathrm{DM})$ while $\mathrm{J} 3$ had the lowest $\left(0.144 \mathrm{ml} 100 \mathrm{~g}^{-1} \mathrm{DM}\right)$ in both years. Strong positive correlation was found between the density of glandular hairs and the essential oil content. Three accessions (588P, J3, JTD3) belong to the perillaldehyde chemotype while GB and PS3 to the dehydro elsholtzia ketone chemotype. All studied accessions can be cultivated in Hungary. For the biomass production the JTD3, while for the essential oil production the $588 \mathrm{P}$ can be recommended.
\end{abstract}

Keywords: Antioxidant - cultivation - intraspecific variability - Lamiaceae, Perilla frutescens

\section{INTRODUCTION}

Perilla (Perilla frutescens (L.) Britt.) is an annual, short-day herb that belongs to the Lamiaceae plant family $[18,26]$. The species has two widely accepted varieties: var. frutescens and var. crispa. The two varieties differ from each other in their morphology and their use. Var. frutescens is taller, the leaves are smooth and usually green, while var. crispa forms smaller bushes and has wrinkled or smooth, green or purple leaves. This latter one is usually used as a medicinal plant in China, Japan and Korea [11]. The plant contains $0.3-1.3 \%$ essential oil in the aboveground parts. The essential oil content (EOC) of Perilla species is higher following the appearance of the flowers [24]. The composition of the essential oil may vary on a large scale. Based on

\footnotetext{
*Corresponding author; e-mail address: radacsi.peter@kertk.szie.hu
} 
this composition, several chemotypes of the species have been described: PA-type containing perillaldehyde, EK-type containing elsholtzia ketone, naginata ketone and shisofuran, DEK-type containing dehydro elsholtzia ketone; DLP-type containing $D$-limonene and piperitone, SF-type containing shisofuran, PK-type containing perilla ketone and isoegoma ketone, PL-type containing perillene, C-type containing citrale, PP-type containing phenylpropanoids like myristicine, elemicin and dillapiole, furthermore PT-type containing piperitenone [4, 5, 6, 16, 25]. For human applications usually the PA chemotype is used, however, only the extracts free of perillaldehyde are recommended to be used [10]. Besides the essential oil several other biologically active compounds are detectable in the plant such as phenoloids, flavonoids, anthocyanins and fatty acids. Perilla is known as a plant of high antioxidant capacity (AOC). The scavenging capacity of methanolic extract of perilla on DPPH radicals was $5.92 \mu \mathrm{g} \mathrm{ml}^{-1}$ in the stalks and $12.34 \mu \mathrm{g} \mathrm{ml}^{-1}$ in the seeds [13]. Gribic et al. [3] measured the AOC with ABTS method (332.52 mg TEAC/100 $\left.\mathrm{g}^{-1} \mathrm{FW}\right)$. They found that the light conditions might influence the AOC of the extracts. Parallel with the AOC, usually a high content of total phenolics (TPC) is measured in the perilla plants $[2,13,14]$. The major phenolic compound of the perilla leaves is rosmarinic acid (RA) which may vary between $39.49 \mathrm{mg} \mathrm{g}^{-1}$ [8] and $314 \mathrm{mg} \mathrm{g}^{-1}$ [7]. Meng et al. [14] measured the highest RA content in perilla accessions of purple and purple-green leaf while in the characteristically green ones the RA content was much lower. Kang and Lee [8] found that the content of phenolic acids was increasing from August to September.

Although the species raises more and more interest, there is still a lack of experiences about the cultivation of different Perilla frutescens accessions in Europe. Therefore, the aim of the current study is to provide information on behavior, special characteristics, production and active ingredients of perilla under Hungarian circumstances.

\section{MATERIALS AND METHODS}

\section{Plant material and growth conditions}

The plant growing was carried out in the experimental field of Szent István University in Budapest (Hungary) in 2014 and 2015.

Five Perilla frutescens accessions (588P, GB, J3, JTD3 and PS3) were selected from the gene bank of the Department of Medicinal and Aromatic Plants, the codes of which are: 588P-LAMIPERI10, GB-LAMIPERI12, J3-LAMIPERI9, JTD3LAMIPERI11 and PS3-LAMIPERI3, respectively. Seeds were sown in greenhouse in the middle of March in 2014 and 2015. The seedlings with two leaves were transplanted to $0.2 \mathrm{~L}$ pots. In the second decade of May twelve individuals from each accession were planted to the open field plots into $50 \times 40 \mathrm{~cm}$ distance. The soil of the experimental field was sandy, the detailed characteristics of the soil are: $\mathrm{pH}_{\mathrm{H}_{2} \mathrm{O}}=6.49$; salt $=0.039 \%$; humus $=1.17 \% ; \mathrm{NO}_{3}-\mathrm{N}=1.24 \mathrm{mg} \mathrm{kg}-1 ; \mathrm{P}_{2} \mathrm{O}_{5}=291 \mathrm{mg} \mathrm{kg}{ }^{-1}$; 
Table 1

Climatic conditions of the experimental field in 2014 and 2015

\begin{tabular}{|l|c|c|c|c|c|c|c|c|}
\hline \multicolumn{7}{|c|}{2014} \\
\hline & Mar. & Apr. & May & June & July & Aug. & Sept. & Oct. \\
\hline $\begin{array}{l}\text { Natural precipitation } \\
(\mathrm{mm})\end{array}$ & 14.8 & 39.0 & 124.8 & 27.4 & 160.6 & 141.8 & 208.0 & 87.0 \\
\hline $\begin{array}{l}\text { Average temperature } \\
\left({ }^{\circ} \mathrm{C}\right)\end{array}$ & 8.9 & 12.4 & 15.0 & 19.2 & 21.5 & 19.3 & 16.3 & 11.5 \\
\hline \multicolumn{7}{|c|}{2015} \\
\hline $\begin{array}{l}\text { Natural precipitation } \\
(\mathrm{mm})\end{array}$ & 20.2 & 8.8 & 89.0 & 56.0 & 48.0 & 84.2 & 26.0 & 139.4 \\
\hline $\begin{array}{l}\text { Average temperature } \\
\left({ }^{\circ} \mathrm{C}\right)\end{array}$ & 6.3 & 10.5 & 15.9 & 19.7 & 22.8 & 22.3 & 18.0 & 9.1 \\
\hline
\end{tabular}

$\mathrm{K}_{2} \mathrm{O}=36.7 \mathrm{mg} \mathrm{kg}^{-1} ; \mathrm{Ca}=0.489 \% ; \mathrm{Mg}=53 \mathrm{mg} \mathrm{kg}^{-1} ; \mathrm{Fe}=109 \mathrm{mg} \mathrm{kg}^{-1} ; \mathrm{Mn}=37.8 \mathrm{mg}$ $\mathrm{kg}^{-1} ; \mathrm{Zn}=1.73 \mathrm{mg} \mathrm{kg}^{-1} ; \mathrm{Cu}=3.47 \mathrm{mg} \mathrm{kg}^{-1} ; \mathrm{CaCO}_{3}<1 \%$. The main climatic conditions are presented in Table 1.

\section{Measurements}

\section{Morphological characteristics}

Plant height of randomly selected five individuals was measured from the root neck to the tip of the shoots, just before harvesting. For leaf investigations, leaves were collected from the third internode from the tip of the shoots. Leaves were scanned with a blue sheet $(14.85 \times 21 \mathrm{~cm})$ as background to identify the leaf area. The pixel number of the blue sheet was determined by the software Adobe Photoshop CS3. Leaves were selected with tool Magic Wand with the threshold 30. The pixel number of the selected area was read in the histogram. Based on the ratio of the area and the pixel number, the leaf area was determined. Ten replicates per accessions were measured. For investigations on glandular hairs circles of $5.5 \mathrm{~mm}$ diameter were cut out from the leaf blade. The number of glandular peltate hairs on the abaxial surface of these blade samples was counted under a stereo-microscope (type BMS 74959). Fifteen replicates per accessions were measured. Leaf area and glandular hair density were determined only in 2014. The glandular hair number of leaves was calculated from the data of glandular hair density and leaf area.

Plants were harvested at the beginning of the flowering (the first buds opened) in the first decade of October both in 2014 and 2015. Each randomly selected individual was cut $5 \mathrm{~cm}$ above ground level. After harvesting, the fresh mass of the plant individuals was measured. Plants were dried in the shade at room temperature to constant weight, and then the dry mass was registered. The dry leaves and flowers were separated from the stems and measured. Leaves and flowers were handled 
together. The leaf ratio (\%) was calculated with the following equivalent: leaf ratio $(\%)=$ dry mass of flowers and leaves/dry mass of the herba* 100 . These measurements were carried out in five replicates/accession. Further laboratory analyses were carried out with bulk samples of the harvested individuals in three replicates in the case of both separate fractions: leaves + flowers and stems.

\section{Antioxidant activity (AOC)}

For measuring the AOC and total phenolic content, $1 \mathrm{~g}$ dried and powdered plant material was extracted by $100 \mathrm{~mL}$ boiling distilled water and was allowed to stand for 24 hours at room temperature. Then the extracts were filtered. After the filterization $3 \times 20 \mathrm{ml}$ sample was taken. The solvent was evaporated from the extract and the dry matter content was identified. The rest of the extract was stored in the freezer until the measurements were performed. The FRAP assay was performed according to the Benzie and Strain [1] procedure with slight modifications. FRAP reagent was prepared freshly to contain sodium acetate buffer (pH 3.6), TPTZ (2,4,6-tripiridil- $S$-triazin) in $\mathrm{HCl}$ and $\mathrm{FeCl}_{3} 6 \mathrm{H}_{2} \mathrm{O}$ solution $(20 \mathrm{mmol} / \mathrm{L})$ in a proportion of $10: 1: 1(\mathrm{v} / \mathrm{v} / \mathrm{v})$, respectively. $10 \mu \mathrm{L}$ of test sample was added to $1.5 \mathrm{~mL}$ of acting FRAP reagent and $40 \mu \mathrm{L}$ distilled water and absorbance was recorded at $593 \mathrm{~nm}$ after 5 minutes by using a Thermo Evolution 201 spectrophotometer. Blank was prepared to contain distilled water instead of extract. FRAP values of samples were calculated from standard curve equation and expressed as $\mathrm{mg}$ ascorbic acid equivalent (AAE) $\mathrm{g}^{-1}$ of dry extract.

\section{Total phenolic content (TPC)}

The TPC was determined by the modified method of Singleton and Rossi [22]. The extracts prepared for AOC analysis were used also for TPC analysis. Sample solution of $0.5 \mathrm{~mL}$ was introduced into a test tube and then $2.5 \mathrm{~mL}$ Folin-Ciocalteau's reagent $(10 \% \mathrm{v} / \mathrm{v})$ was added. After $1 \mathrm{~min}$ of incubation $2 \mathrm{~mL}$ of sodium carbonate $(0.7 \mathrm{M})$ was added. The absorbance of the resulting colour was measured at $760 \mathrm{~nm}$ with an above mentioned spectrophotometer after a $5 \mathrm{~min}$ incubation period in hot water $\left(50{ }^{\circ} \mathrm{C}\right)$. Quantification was done with respect to the standard curve of gallic acid $(0.3 \mathrm{M})$ and the TPC of the sample was expressed as mg of gallic acid equivalents (GAE) per g of dry mass of extract. Blank was prepared to contain distilled water instead of extract.

\section{Essential oil content and composition (EOC)}

The EOC was measured with a Clevenger-type apparatus according to the VII. Hungarian Pharmacopoeia [19]. GC analysis was carried out using an Agilent 


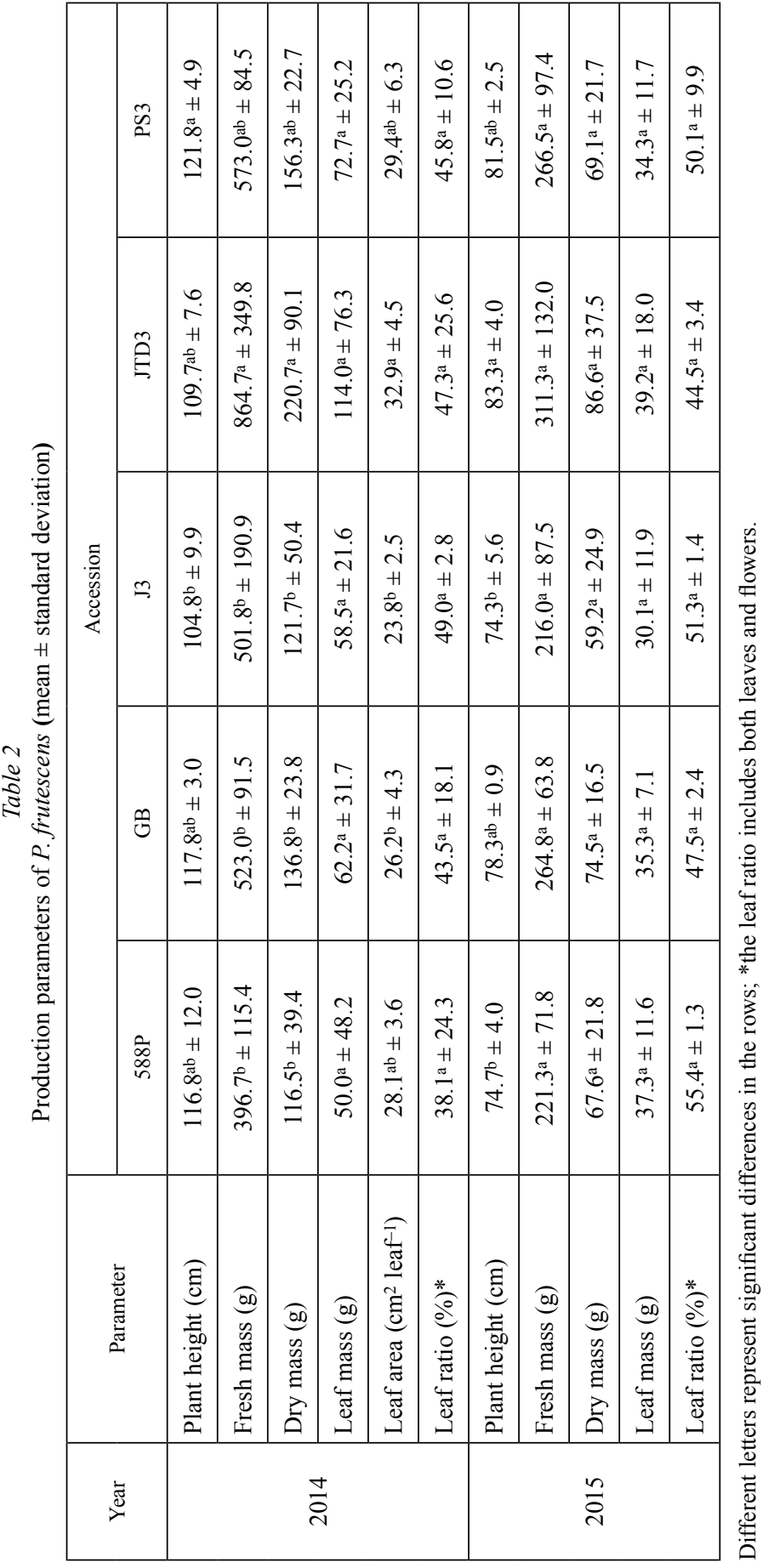

Acta Biologica Hungarica 68, 2017 
Technologies $6890 \mathrm{~N}$ instrument equipped with HP-5MS capillary column $(30 \mathrm{~m} \times 0.25 \mathrm{~mm}$, film thickness $0.25 \mu \mathrm{m}$ ), working with the following temperature program: initial temperature $60^{\circ} \mathrm{C}$, heating by a rate of $3{ }^{\circ} \mathrm{C} \mathrm{min}-1$ up to $240{ }^{\circ} \mathrm{C}$; the final temperature was maintained for $5 \mathrm{~min}$; injector and detector temperatures: $250{ }^{\circ} \mathrm{C}$; carrier gas: helium (constant flow rate: $1 \mu \mathrm{min}^{-1}$ ); split ratio: 30:1, injection volume $0.2 \mu \mathrm{L}(10 \%, n$-hexane). The GC-MS analysis was carried out using an Agilent Technologies 6890 N GC equipped with an Agilent Technologies MS 5975 detector according to the parameters given above. Ionization energy was $70 \mathrm{eV}$. The mass spectra were recorded in full scan mode, which revealed the total ion current (TIC) chromatograms. A mixture of aliphatic hydrocarbons (C9-C23) in $n$-hexane was injected under the above mentioned temperature program to calculate the linear retention indices using the generalized equation of Van Den Dool and Kratz [23]. The mass spectra and linear retention indices (LRI) were compared with those of commercial libraries (NIST, Wiley) and our GC-MS database built up from spectral data obtained from GC-MS data of standards (Sigma/Aldrich). The proportion of the individual compounds was expressed as total area percentages.

\section{Statistical analysis}

The results were analysed with the IBM SPSS Statistics 19 software. The results are given as mean \pm standard deviation (SD) and one-way analysis of variance (ANOVA) was used for comparison of more than two means. Normality of the residuals was proved according the Kolmogorov-Smirnov method. Homogeneity of variances was tested by Levene's method. Treatments were separated by Games-Howell's or Tukey's post hoc tests, depending on whether homogeneity assumption was violated or not. For evaluating the connection of data Pearson correlations were performed.

\section{RESULTS}

The leaf color of the investigated accessions was not uniform. Accession 588P showed purple-green color on the adaxial side of the leaves while they were purple in the abaxial side. Both sides of the leaves of accessions GB, J3, JTD3 and PS3 had dark purple colour. The leaf margin of all accession was serrate. In the case of 588P the length and width of teeth were approximately the same while in the other accessions the length of teeth was the double of the width.

Significant differences were detected in the plant height in both years (Table 2). The highest plants were registered in accessions PS3 (2014) and JTD3 (2015) while the smallest ones in J3. Between the smallest and the tallest accessions there was a difference of $17.0 \mathrm{~cm}$ in 2014 and $9.0 \mathrm{~cm} 2015$. JTD3 accession produced the highest fresh and dry biomass in both years. In 2014 the fresh and dry mass of this taxon was significantly higher than that of accessions 588P, GB and J3 (Table 2). In 2015 the differences in biomass were not significant; however, the JTD3 accession had 43\% 


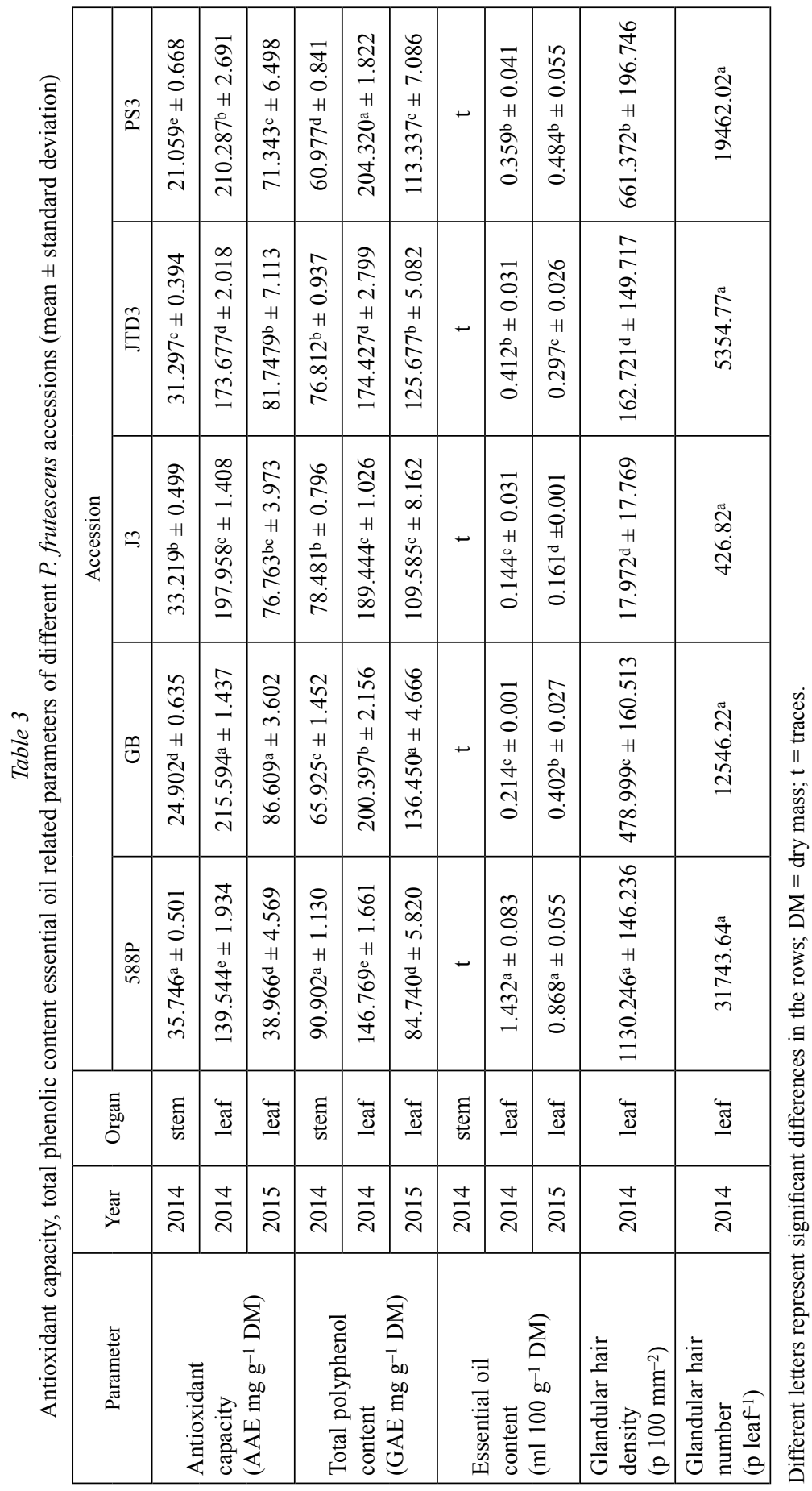




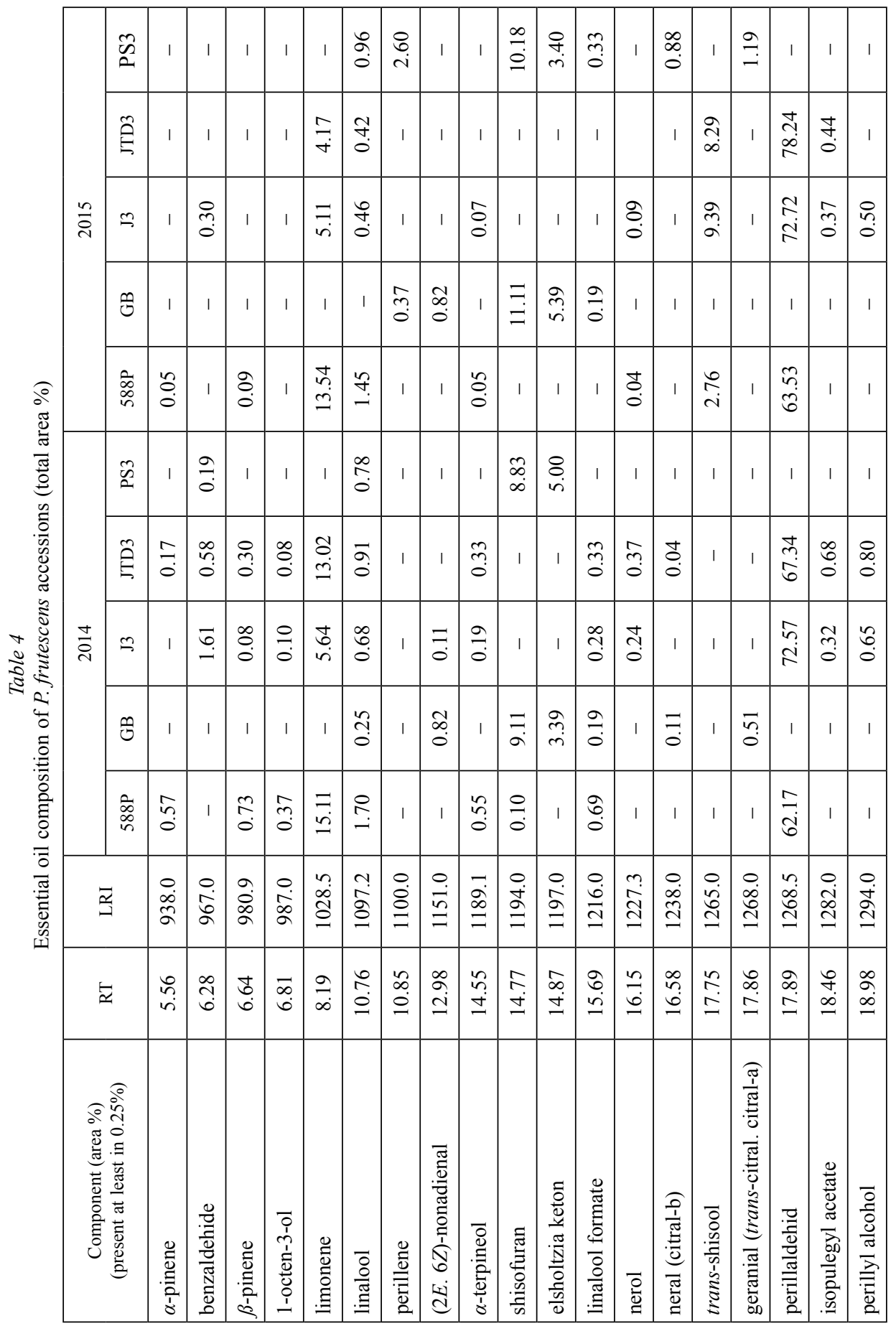




\begin{tabular}{|c|c|c|c|c|c|c|c|c|c|c|c|c|c|c|c|c|c|c|c|}
\hline \multirow{5}{*}{$\stackrel{n}{\stackrel{2}{\sim}}$} & 1 & $\begin{array}{l}\stackrel{\circ}{\circ} \\
\text { i }\end{array}$ & $\begin{array}{l}\infty \\
\infty \\
0\end{array}$ & I & 1 & $\stackrel{\grave{\jmath}}{\grave{\jmath}}$ & $\begin{array}{l}8 \\
0\end{array}$ & ָָ & 1 & $\underset{0}{0}$ & $\stackrel{ \pm}{0}$ & 1 & $\vec{b}$ & $\begin{array}{l}\text { in } \\
i n\end{array}$ & 1 & $\begin{array}{l}\text { ț } \\
\text { d }\end{array}$ & $\begin{array}{l}\mathfrak{g} \\
i \\
i\end{array}$ & $\vec{m}$ & $\begin{array}{l}2 \\
n \\
0 \\
0\end{array}$ \\
\hline & 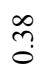 & 1 & 1 & 1 & $\overrightarrow{\tilde{O}}$ & $\hat{n}$ & $\stackrel{2}{2}$ & 1 & 1 & $\stackrel{9}{+}$ & 1 & 1 & 1 & $\begin{array}{l}\infty \\
0 \\
0\end{array}$ & 1 & 1 & $\frac{\dot{\sigma}}{\sigma}$ & $\vec{\sigma}$ & $\begin{array}{l}n \\
\infty \\
\alpha \\
\alpha\end{array}$ \\
\hline & 1 & 1 & 1 & 1 & 1 & 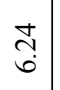 & 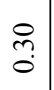 & 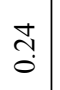 & $\begin{array}{l}\tilde{O} \\
\dot{i}\end{array}$ & 1 & 1 & 1 & 1 & $\stackrel{n}{=}$ & 1 & 1 & $\begin{array}{l}\vec{b} \\
\dot{\infty}\end{array}$ & $\begin{array}{l}0 \\
\stackrel{0}{0} \\
\end{array}$ & $\hat{\curvearrowright}$ \\
\hline & 1 & $\begin{array}{l}\qquad 8 \\
\dot{+}\end{array}$ & $\frac{\Omega}{i}$ & I & 1 & $\begin{array}{l}+ \\
\infty \\
\sigma\end{array}$ & ๗ે. & $\begin{array}{l}\infty \\
n \\
0\end{array}$ & 1 & $\begin{array}{l} \pm \\
\dot{m}\end{array} \mid$ & 1 & 1 & $\stackrel{?}{\circ}$ & 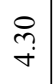 & 1 & $\stackrel{\infty}{\stackrel{\infty}{+}}$ & ت্ & 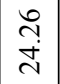 & $\left|\begin{array}{c}0 \\
n \\
\infty \\
\infty\end{array}\right|$ \\
\hline & 1 & $\frac{1}{0}$ & 1 & 1 & 1 & $\underset{\sigma}{\sigma}$ & $\begin{array}{l}\stackrel{8}{0} \\
\stackrel{0}{*}\end{array}$ & $\vec{\beth}$ & 1 & $\begin{array}{l}0 \\
\\
r\end{array}$ & $\begin{array}{l} \pm \\
0\end{array}$ & 1 & $\stackrel{2}{\circ}$ & $\stackrel{\infty}{\leftrightarrows}$ & 1 & 1 & $\underset{\infty}{\infty}$ & $\mid \begin{array}{c}0 \\
0 \\
\infty\end{array}$ & $\begin{array}{l} \pm \\
\infty \\
a \\
\alpha\end{array}$ \\
\hline \multirow{5}{*}{$\stackrel{ \pm}{\vec{N}}$} & 1 & $\underset{0}{8}$ & 守 & I & 1 & $\stackrel{\tilde{n}}{\mathrm{i}}$ & 1 & 1 & 1 & 1 & 1 & 1 & $\stackrel{m}{?}$ & $\begin{array}{c}\stackrel{R}{i} \\
i\end{array}$ & 1 & 1 & $\stackrel{\tilde{m}}{a}$ & $\begin{array}{l}0 \\
\text { ì } \\
\text { in }\end{array}$ & $\begin{array}{l}\hat{n} \\
\dot{\alpha} \\
2\end{array}$ \\
\hline & 1 & 1 & 1 & $\stackrel{0}{0}$ & $\left|\begin{array}{l}\infty \\
0 \\
0 \\
0\end{array}\right|$ & $\underset{⿱ 亠}{\stackrel{\infty}{r}}$ & $\begin{array}{l}\infty \\
\stackrel{n}{0}\end{array}$ & $\stackrel{8}{:}$ & 1 & 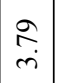 & $\begin{array}{l}0 \\
\dot{0}\end{array}$ & $\begin{array}{l}0 \\
0 \\
0\end{array}$ & $\begin{array}{l}0 \\
0 \\
0\end{array}$ & $\tilde{\sigma}$ & 1 & I & $\begin{array}{l} \pm \\
\dot{\infty} \\
\infty\end{array}$ & $\begin{array}{l}\tilde{D} \\
\dot{J} \\
\tilde{J}\end{array}$ & $\begin{array}{l}0 \\
\infty \\
\vdots \\
\vdots\end{array}$ \\
\hline & 1 & 1 & 1 & $\overrightarrow{\widetilde{o}}$ & $\begin{array}{l}\infty \\
0 \\
0 \\
0\end{array}$ & $\underset{0}{\infty}$ & $\stackrel{f}{f}$ & $\begin{array}{l}\stackrel{\infty}{\infty} \\
0 \\
0\end{array}$ & 1 & $\begin{array}{l}n \\
\infty \\
n\end{array} \mid$ & 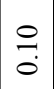 & ণิ & $\stackrel{8}{8}$ & $\stackrel{\sim}{\sim}$ & $\stackrel{\mathfrak{I}}{\circ}$ & 1 & $\begin{array}{l}\infty \\
\infty \\
i \\
i \\
\infty\end{array}$ & $\begin{array}{l}0 \\
0 \\
0\end{array}$ & $\vec{\nabla}$ \\
\hline & 1 & $\begin{array}{l}\vec{i} \\
\text { î }\end{array}$ & $\stackrel{\simeq}{\leftrightarrows}$ & I & 1 & $\stackrel{3}{r}$ & $\stackrel{\infty}{\stackrel{\infty}{0}}$ & $\stackrel{n}{n}$ & 1 & $\begin{array}{l}n \\
\tilde{b} \\
\dot{n}\end{array} \mid$ & 1 & 1 & $\stackrel{m}{0}$ & 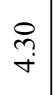 & 1 & 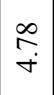 & $\stackrel{\vec{n}}{\stackrel{n}{n}}$ & $\frac{n}{n}$ & $\begin{array}{c}\tilde{o} \\
\dot{\alpha}\end{array}$ \\
\hline & 1 & $\stackrel{\hat{0}}{0}$ & 1 & $\begin{array}{l}0 \\
\stackrel{?}{0}\end{array}$ & 1 & શે & $\begin{array}{l}\infty \\
\infty \\
0\end{array}$ & $\stackrel{\leftrightarrow}{\circ}$ & 1 & $\underset{+}{\stackrel{q}{+}}$ & $\overrightarrow{\widehat{\sigma}}$ & ?n & $\stackrel{9}{0}$ & $\begin{array}{l}\vec{\infty} \\
\stackrel{0}{0}\end{array}$ & $\begin{array}{l}0 \\
0 \\
0\end{array}$ & 1 & $\underset{\infty}{ \pm}$ & $\stackrel{\nabla}{\ddot{\sim}}$ & 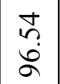 \\
\hline 곡 & 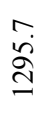 & $\begin{array}{l}\stackrel{0}{\grave{~}} \\
\text { İ }\end{array}$ & $\begin{array}{l}0 \\
\dot{0} \\
\stackrel{0}{0}\end{array}$ & $\begin{array}{l}\infty \\
\dot{0} \\
\stackrel{0}{=} \\
\end{array}$ & $\begin{array}{l}0 \\
\dot{a} \\
\dot{J}\end{array}$ & $\begin{array}{l}\stackrel{0}{\dot{D}} \\
\stackrel{+}{ \pm}\end{array}$ & $\begin{array}{l}\stackrel{\sim}{*} \\
\stackrel{f}{ \pm}\end{array}$ & $\begin{array}{l}n \\
\stackrel{\infty}{+} \\
\stackrel{\infty}{ \pm}\end{array}$ & $\begin{array}{l}0 \\
\dot{0} \\
\stackrel{9}{ \pm}\end{array}$ & $\begin{array}{c}0 \\
\dot{0} \\
\dot{g} \\
-\end{array} \mid$ & $\begin{array}{l}\stackrel{a}{\hat{\nu}} \\
\hat{\Omega}\end{array}$ & $\begin{array}{l}0 \\
\stackrel{0}{0} \\
\stackrel{2}{n}\end{array}$ & $\begin{array}{l}\circ \\
\dot{\infty} \\
\stackrel{0}{n}\end{array}$ & $\begin{array}{l}0 \\
\ddot{2} \\
\stackrel{2}{n}\end{array}$ & 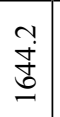 & 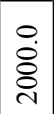 & \multirow[b]{3}{*}{ 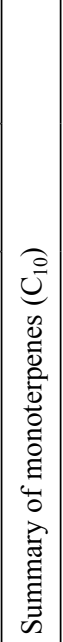 } & \multirow[b]{3}{*}{ 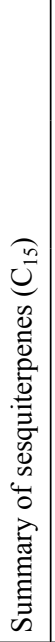 } & \multirow[b]{3}{*}{ 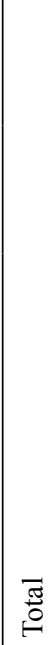 } \\
\hline$\overleftrightarrow{\sim}$ & $\begin{array}{l}\text { to } \\
\stackrel{a}{-}\end{array}$ & $=$ & $\begin{array}{l}\dot{J} \\
\stackrel{2}{2}\end{array}$ & $\underset{⿱}{\stackrel{J}{\sim}}$ & $\begin{array}{l}\tilde{6} \\
\tilde{n} \\
\tilde{v}\end{array} \mid$ & $\begin{array}{l}\infty \\
\dot{0} \\
\dot{\lambda}\end{array}$ & $\begin{array}{l}\hat{0} \\
\vec{d}\end{array}$ & $\begin{array}{l}\infty \\
\overrightarrow{0} \\
\stackrel{\sim}{N}\end{array}$ & $\underset{\stackrel{i}{i}}{\stackrel{i}{i}}$ & $\begin{array}{l}2 \\
i \\
0 \\
i\end{array}$ & $\begin{array}{l}\infty \\
\stackrel{\sim}{\sim}\end{array}$ & $\begin{array}{l}\tilde{\imath} \\
\grave{\lambda}\end{array}$ & $\begin{array}{l}\infty \\
\stackrel{\lambda}{\hat{\lambda}}\end{array}$ & 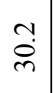 & $\begin{array}{l}\text { ָे } \\
\text { ñ }\end{array}$ & $\stackrel{\hat{N}}{\grave{g}}$ & & & \\
\hline 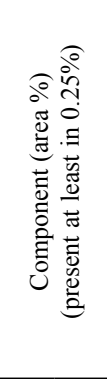 & 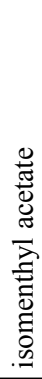 & 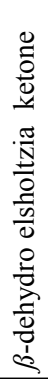 & 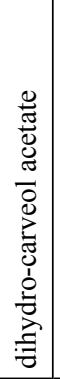 & $\begin{array}{l}\overline{\overrightarrow{0}} \\
\overrightarrow{\mathbb{D}_{0}} \\
\overrightarrow{\bar{c}}\end{array}$ & 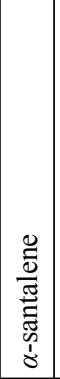 & 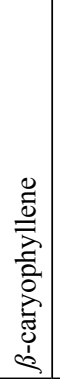 & 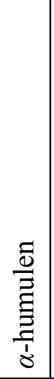 & 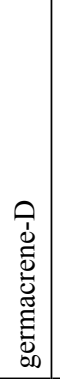 & 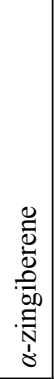 & 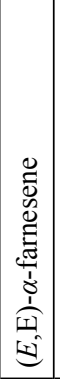 & 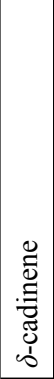 & $\begin{array}{l}\overrightarrow{0} \\
: \overline{0} \\
\overline{0} \\
=\end{array}$ & 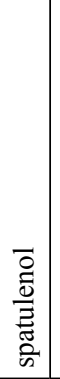 & 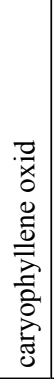 & 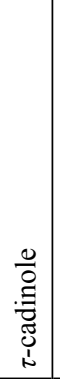 & 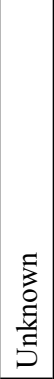 & & & \\
\hline
\end{tabular}


higher fresh mass and $46 \%$ higher dry mass even this year compared to accession $\mathrm{J} 3$ which produced the lowest yields.

As the leaves are the most frequently used plant parts in the Perilla genus, their mass is of high importance. Dry leaf mass of accession JTD3 proved to be the highest one in both years. Statistical analysis showed significant differences only in 2014. The leaf ratio varied between $38.1-55.4 \%$ in the investigated accessions and in this context no statistical differences were observable during the two years of the experiment (Table 2). The smallest leaves were produced by J3. Similarly to the biomass production, the biggest leaves were grown on the JTD3 plants. The difference of leaf areas between J3 and JTD3 accessions were $9.1 \mathrm{~cm}^{2}$ leaf $^{-1}$ in 2014 (Table 2).

The AOC of $P$. frutescens accessions varied in a wide range in the two years (Table 3). AOC was detectable both in leaf and stem fractions, although it is much lower in the stems than in the leaves. On the one hand, the highest AOC in the stems was measured in 588P and the lowest in GB and PS3. On the other hand, in the leaves accession GB had the highest AOC while 588P had the lowest one in both years (Table 3). Similarly to the AOC, the TPC was much lower in the stems, than in the leaves. Concerning the stems, accession 588P had significantly higher TPC than other accessions did but in the leaves the highest TPC was detected at PS3 (2014) and GB (2015).

The stems contained essential oil only in traces (Table 3) while in the leaf fractions the investigated accessions showed wide variability. Highest EOC values were recorded in 588P $(1.432 \% \pm 0.083$ in 2014 and $0.868 \% \pm 0.055$ in 2015). Compared to these, all measured essential oil concentrations were significantly lower in other accessions. J3 showed 10- and 5-fold lower EOC $(0.144 \% \pm 0.031$ in 2014 and $0.161 \% \pm 0.001$ in 2015) compared to 588P. The essential oil accumulates in the glandular hairs on the leaf of Perilla. Till now, no information was reported about the possible connection between the number of glands and essential oil content of $P$. frutescens. Variety $588 \mathrm{P}$ has 63 -fold higher glandular hair density than $\mathrm{J} 3$ (Table 3). In the number of glandular hairs per leaf we found the same differences. $588 \mathrm{P}$ had over 30,000 glandular hairs on the abaxial leaf surface while J3 had less than 500 .

In the essential oil composition we found well established differences among the accessions (Table 4). Based on the composition of essential oil, the accessions were divided into two groups. Perillaldehyde was detected as a main component of accessions 588P, J3 and JTD. The total area percentage of this compound varied between $62.17 \%$ and $78.24 \%$. Besides the perillaldehyde only 3 components had a higher ratio than $5 \%$. Limonene, as the precursor of perillaldehyde, was the second highest component with 5.11-15.11\%. $\beta$-Caryophyllene was present in the oil with 5.29-9.84\%, while $(E, E)$ - $\alpha$-farnesene with $1.40-7.36 \%$. The main components of the essential oil varied only mildly in the two years. A single difference represents trans-shisool, which was detectable only in 2015. In the second group of accessions (GB and PS3) the major component was the $\beta$-dehydro elsholtsia ketone with a ratio of $42.06-$ $76.06 \%$. The shisofuran was present in both accessions (8.83-11.11\%) while $\beta$-caryophyllene content varied between 2.23 and $12.99 \%$. Besides the main compo- 
nents we could not find any taxon-specific compounds. There was no detectable a clear tendency in the ratio of mono- and sesquiterpenes. The essential oil was characterized mainly by monoterpenes (62.49-91.94\%).

\section{DISCUSSION}

The tested P. frutescens accessions showed well detectable differences both in their production and in the biologically active constituents. We can conclude that JTD3 accession has the highest production capacity while accession 588P possesses the lowest one. Earlier, Lee and Yang [12] proved that the climatic conditions and the time of sowing may influence the growth characteristics of perilla. Tallest plants were over $1.5 \mathrm{~m}$ in their study and also the fresh mass of the herb (1800 g plant $\left.{ }^{-1}\right)$ and that of the leaves $\left(\sim 500 \mathrm{~g} \mathrm{plant}^{-1}\right)$ were much higher than in our experiment. Omer et al. [17] described also taller plants with bigger fresh mass.

We did not find correlation between the leaf area and the number of glandular hairs, but strong positive correlation $(\mathrm{R}=0.734, \mathrm{p}=0.002)$ was found between the density of glandular hairs and the EOC. Practically, it means that the higher glandular hair density indicates a higher EOC. In sweet basil similar conclusion could not be established: correlation between the density of glandular hairs and EOC was not detectable [20]. Further investigations are necessary to test the validity of glandular hair density as a possible marker of essential oil content.

High AOC and TPC were reported by former references in case of stems of perilla $[2,13]$. We also detected both parameters in the stems although they were higher in the leaves. A strong positive correlation was detected between the AOC and TPC data $(\mathrm{R}=0.889, \mathrm{p}=0.000)$. Similarly, in the related species, lemon balm and thyme proved to have tight connection between these values [15]. The most important phenolic compound in perilla is the RA, which may also attribute a strong AOC [7, 8]. The lowest AOC and TPC were found in the 588P accession which has a greenish leaf colour. Some of the essential oil components (thymol, carvacrol) in other species proved as responsible molecules for the strong AOC [21]. However, we did not find correlation between essential oil composition and the AOC.

The essential oil composition of the investigated accessions was comparable with former references $[5,6,16,25]$. The accessions could be classified into two chemotypes: perillaldehyde (PA) and dehydro eslholtzia ketone (DEK) types. The biosynthetic pathway of the main essential oil components of perilla is mainly known. Two independent genes with multiple alleles are determining the major components of the essential oil. The composition of the essential oil is mainly determined genetically [9]. In harmony with this, there were no changes in the main component spectrum during the investigated two years.

It could be established that the weather conditions of the two years exhibited a strong influence on several plant characteristics. In 2015, only the half of the natural precipitation has fallen than in the vegetation period of the previous year while the average temperature of months was usually higher than it was in 2014. Due to this, 
we found that production related parameters (plant height, fresh mass, dry mass, leaf mass) and level of biologically active constituents were lower in 2015 than in 2014.

Based on the investigated accessions we can conclude that for different purposes different accessions are recommended. If the aim is the high biomass production, the best choice is JTD3. For essential oil production, obviously 588P is recommended. The highest antioxidant capacity was shown by PS3. However, there is a lack of knowledge about the toxicity of its main essential oil components.

\section{ACKNOWLEDGEMENT}

This project was supported by the ÚNKP-16-4 New National Excellence Program of the Ministry of Human Capacities.

\section{REFERENCES}

1. Benzie I. F., Strain J. J. (1996) The ferric reduction ability of plasma (FRAP) as a measure of "Antioxidant Power": the FRAP assay. Anal. Biochem. 239, 70-76.

2. Chou, H.-J., Kuo, J.-T., Lin, E.-S. (2009) Comparative antioxidant properties of water extracts from different parts of beefsteak plant (Perilla frutescens). J. Food Drug Anal. 17, 489-496.

3. Grbic, N., Paschko, K., Pinker, I., Böhme, M. H. (2016) Effect of different light spectra by using coloured films on growth, fresh and dry matter, nutrient solution uptake and secondary metabolites of Perilla frutescens (L.) Britt. Sci. Hortic. 210, 93-98.

4. Ito, M., Honda, G. (2007) Geraniol synthases from perilla and their taxonomical significance. Phytochemistry 68, 446-453.

5. Ito, M., Toyoda, M., Kamakura, S., Honda, G. (2002) A new type of essential oil from Perilla frutescens from Thailand. J. Essent. Oil Res. 14, 416-419.

6. Ito, M., Toyoda, M., Nakano, Y., Kiuchi, F., Honda, G. (1999) Chemical composition of essential oils from Perilla setoyensis, A new species of Wild Perilla in Japan. J. Essent. Oil Res. 11, 669-672.

7. Jun, H.-I., Kim, B.-T., Song, G.-S., Kim, Y.-S. (2014) Structural characterization of phenolic antioxidants from purple perilla (Perilla frutescens var. acuta) leaves. Food Chem. 148, 367-372.

8. Kang, N. S., Lee, J. H. (2011) Characterisation of phenolic phytochemicals and quality changes related to the harvest time from the leaves of Korean purple perilla (Perilla frutescens). Food Chem. $124,556-562$.

9. Koezuka, Y., Honda, G., Tabata, M. (1986) Genetic control of the chemical composition of volatile oils in Perilla frutescens. Phytochemistry 25, 859-863.

10. Kosuna, K., Haga, M. (1997) The development and application of perilla extract as an anti-allergic substance. In Yu, H., Kosuna, K., Haga, M. Perilla (ed.). The Genus Perilla. Harwood Academic Publisher, 83-93.

11. Lee, J. K., Ohnishi, O. (2001) Geographic differentiation of morphological characters among Perilla crops and their weedy types in East Asia. Breeding Sci. 51, 247-255.

12. Lee, Y.-J., Yang, C.-M. (2006) Growth behavior and perillaldehyde concentration of primary leaves of Perilla frutescens (L.) Britton grown in different seasons. Crop Environ. Bioinf. 3, 135-146.

13. Lin, E.-S., Chou, H.-J., Kuo, P.-L., Hoang, Y.-C. (2010) Antioxidant and atiproloferative activities of methanolic extracts of Perilla frutescens. J. Med. Plants Res. 4, 477-483.

14. Meng, L., Lozano, Y. F., Gaydou, E. M., Li, B. (2009) Antioxidant activities of polyphenols extracted from Perilla frutescens varieties. Molecules 14, 133-140.

15. Németh-Zámbori, É., Pluhár, Z., Szabó, K., Malekzadeh, M., Radácsi, P., Inotai, K., Komáromi, B., Seidler-Lozykowska, K. (2016) Effect of water supply on growth and polyphenols of lemon balm (Melissa officinalis L.) and thyme (Thymus vulgaris L.). Acta Biol. Hung. 67, 64-74. 
16. Nitta, M., Kobayashi, H., Ohnishi-Kameyama, M., Nagamine, T., Yoshida, M. (2006) Essential oil variation of cultivated and wild Perilla analyzed by GC/MS. Biochem. Syst. Ecol. 34, 25-37.

17. Omer, E. A., Khattab, M. E., Ibrahim, M. E. (1998) First cultivation trial of Perilla frutescens L. in Egypt. Flavour Frag. J. 13, 220-225.

18. Pandey, A., Bhatt, K. C. (2008) Diversity distribution and collection of genetic resources of cultivated and weedy type in Perilla frutescens (L.) Britton var. frutescens and their uses in Indian Himalaya. Genet. Resour. Crop Ev. 55, 883-892.

19. Pharmacopoeia Hungarica $7^{\text {th }}$ ed. (1986) Medicina Könyvkiadó, Budapest, 1, 395-398.

20. Radácsi, P. (2014) Effect of water supply on the physiological characteristics, production and active substances of sweet basil (Ocimum basilicum L.) and summer savory (Satureja hortensis L.). Doctoral thesis, Corvinus University of Budapest.

21. Ramos, M., Beltrán, A., Peltzet, M., Valente, A. J. M., Garrigós, M. C. (2014) Release and antioxidant activity of carvacrol and thymol from polypropylene active packaging films. LWT-Food. Sci. Technol. $58,470-477$

22. Singleton, V. L., Rossi, J. A. (1965) Colorimetry of total phenolics with phosphomolybdic-phosphotungstic acid reagents. Am. J. Enol. Vitic. 16, 144-158.

23. Van Den Dool, H., Kratz, P. (1963) A generalization of the retention index system including linear temperature programmed gas-liquid partition chromatography. J. Chromatogr. A. 11, 463-471.

24. Yu, H.-C. (1997) I. Introduction In: Yu, H., Kosuna, K., Haga, M. Perilla (eds), The Genus Perilla. Harwood Academic Publisher, 1-8.

25. Zhang, X., Wu, W., Zheng, Y., Chen, L., Qianrong, C. (2009) Essential oil variations in different Perilla L. accessions: chemotaxonomic implications. Plant Syst. Evol. 281, 1-10.

26. Zhou, X. J., Yan, L. L., Yin, P. P., Shi, L. L., Zhang, J. H., Liu, Y. J., Ma, C. (2014) Structural characterisation and antioxidant activity evaluation of phenolic compounds from cold-pressed Perilla frutescens var. arguta seed flour. Food Chem. 164, 150-157. 